\title{
Presentation of Neuroendocrine Self in the Thymus: Toward a Novel Type of Vaccine/Immunotherapy
}

\author{
Vincent Geenen*, Fabienne Brilot, Isabelle Hansenne, Céline Louis and Henri \\ Martens
}

University of Liege Center of Immunology (CIL), Institute of Pathology CHU-B23, B-4000 LiegeSart Tilman, Belgium

\begin{abstract}
Slightly after the emergence some 400 millions years ago of the first signs of adaptive immune response, tolerogenic pathways developed in order to preserve the integrity of self from potential autoimmune toxicity. Amongst those tolerogenic pathways, the thymus occupies a central place both by deleting self-reactive $\mathrm{T}$ cells that are produced in the thymus during random recombination of gene segments encoding the variable parts of the T-cell receptor for antigen (TCR) (negative selection), and by generating self-antigen specific regulatory $\mathrm{T}$ cells ( $\mathrm{Tr}$ ). A repertoire of neuroendocrine-related genes are transcribed by thymic stromal cells - epithelial and 'nurse' cells (TEC/TNC), dendritic cells (DC) and macrophages (M $\Phi)$ - in such a way that a dominant protein precursor is expressed in the thymus environment. Oxytocin (OT) and neurokinin A (NKA) are the dominant thymic precursors for the neurohypophysial hormone and tachykinin families, respectively. With regard to the insulin gene family, all members are transcribed following a precise cell topography and hierarchy in the profile of gene expression: $I G F 2(\mathrm{TEC} / \mathrm{TNC})>I G F 1(\mathrm{M} \Phi)>>I N S$ (medullary TEC and/or DC). This hierarchy implies that IGF-2 is more tolerated than IGF-1, and much more than Insulin (Ins). The low level of INS transcription in the thymus also explains why Ins displays immunogenic properties, as well as the significant prevalence $( \pm 40 \%)$ of anti-Ins autoantibodies in the general population. Ins administration failed in providing tolerance or protection toward islet $B$ cells in type 1 diabetes (T1D). In contrast, the presentation of IGF-2 B11-25, the homologous sequence of Ins B9-23, to peripheral blood mononuclear cells (PBMC) isolated from DQ8+ T1D adolescents significantly increases IL-10 secretion and ILIO expression. Given the potent regulatory/suppressive properties of IL-10 on the autoimmune response toward islet $\beta$ cells, these data support that IGF-2 derived sequences constitute a strong basis for the development of an antigen-specific driven tolerogenic approach for T1D prevention and/or cure.
\end{abstract}

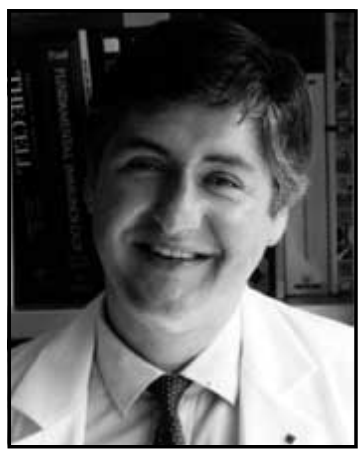

Keywords: Thymus - Self-antigen - Type 1 diabetes - Insulin-like growth factor 2 (IGF-2).

\section{A BROAD OVERVIEW OF THYMUS PHYSIOLOGY}

The physiology of the immune system is characterized by three fundamental properties: response diversity, induction of memory cells, and inability to aggress host components (self-tolerance). The thymus is the very unique lymphoid structure specialized both in the stochastic generation of diversity of $\mathrm{T}$ cell antigen receptors (TCR) and in the establishment of central self-tolerance. This latter results from the clonal deletion of self-reactive $\mathrm{T}$ cells emerging during intrathymic random recombination of variable TCR segment genes [1], as well as the generation of self-antigen specific regulatory $\mathrm{T}$ cells $(\mathrm{Tr})$ [2,3]. Even antigendependent $\mathrm{B}$ cell tolerance is most often due to absence of thymus-derived T-cell help [4].

The dual physiological role of the thymus in $\mathrm{T}$ cell development (thymopoiesis) and self-tolerance induction is ensured by the cellular components of the thymic stroma. Thymic epithelial cells (TEC) represent the major cell population $( \pm 80 \%)$ of the thymic stroma and are distributed

*Address correspondence to this author at the Director of Liege Center of Immunology Institute of Pathology CHU-B23 B-4000 Liege-Sart Tilman / Belgium; Tel: +32 436625 50; Fax: +32 436629 77; E-mail: vgeenen@ulg.ac.be in three regions: subcapsular cortex, inner cortex and medulla. During embryonic development, TEC derive from epithelial stem cells that have been recently identified in the primitive endoderm [5,6]. In the outer cortex, thymic "nurse" cells (TNC) are large TEC that engulf up to 50 thymocytes (immature T cells) inside leaflets of TNC plasma membrane [7]. Derived from bone marrow, thymic dendritic cells (DC) are located at the cortico-medullary junction, while macrophages are distributed throughout the thymic stroma without any precise topography. From primitive hematopoietic sites, T-cell progenitors migrate into the thymus, proliferate in the outer cortex, and pursue their differentiation program from cortex to medulla at the contact of thymic stromal cells. Presentation of self-antigens to randomly rearranged TCR constitutes one major component of the multiple signaling pathways between thymic stromal cells and pre-T cells. This process responsible for the deletion of self-reactive $\mathrm{T}$ cells is very powerful since only $1-2 \%$ of pre-T cells will leave the thymus in a state of competence against non self and tolerance to self [8].

To explain this dual role of the thymus, the affinityavidity model [9] proposes that clonal deletion is the fate of $\mathrm{T}$ cells bearing a TCR with high affinity for self-antigens presented at high density by thymic major histocompatibility 
complex (MHC) molecules. T cells with a low-affinity TCR or confronted with self-antigens at too low density will die by "neglect", while those with intermediate affinity/avidity will be selected for further development. It is, however, important to note that, given the rather low affinity of a given TCR for its specific antigen $\left(K_{D}\right.$ around $\left.10^{-7} \mathrm{M}\right)$, the biological meaning of lower affinities may be questioned.

A significant advance in our understanding of thymic physiology was gained with the demonstration that a repertoire of neuroendocrine-related, as well as peripheral antigen-encoding genes, are transcribed in thymic stromal cells [10-15]. Based on the intrathymic transcription of neurohypophysial and tachykinin genes, another model was proposed to explain at the molecular level the paradox of thymus physiology. Oxytocin (OT) and neurokinin A (NKA) are expressed in TEC/TNC as the dominant members of the neurohypophysial and tachykinin families, respectively $[16,17]$. Thymic OT and NKA precursors engage two distinct types of interactions with developing T cells. First, they are the source of ligands that bind with high affinity to neuroendocrine receptors expressed by pre-T cells. In this type of cryptocrine signaling [18,19], those ligands are not secreted but targeted to the outer surface of thymic stromal cell plasma membrane. Secondly, the same precursors undergo another type of processing and deliver self-antigens that are presented by the thymic MHC machinery [20,21]. Thus, in the thymus, a confrontation occurs throughout life between previously established neuroendocrine principles and a recently evolved system characterized by stochastic generation of its response diversity. According to this model, the intrathymic presentation of neuroendocrine self is responsible for the establishment of central self-tolerance of neuroendocrine functions [22].

\section{THE THYMIC INSULIN-LIKE GROWTH FACTOR AXIS}

During further experimentation with this working model, using a battery of specific polyclonal and monoclonal antibodies, a strong immunoreactivity for insulin-like growth factor (IGF) 2 was detected in the epithelium of human and rat thymi [23]. Although the protein was detected in cell bodies of human TEC primary cultures, no IGF-2 could be detected in the incubation media. In addition, using confocal microscopy, immunoreactive (IR) IGF-2 was evidenced at the outer surface of cultured human TEC plasma membrane (Achour et al., PhD Thesis, University of Liege, Faculty of Science). IR IGF-1 was also identified in thymic stromal cells with a thymic macrophage-like morphology and topography. With two monoclonal antibodies directed against distinct epitopes of insulin, we did not find any significant immunoreactivity in human thymic lobules although some faint insulin immunoreactivity could be discussed in some subsets of medullary TEC. Nevertheless, from those studies, it was clear that IGF-2 is by far the dominant insulin-related protein first encountered by immature $\mathrm{T}$ cells during their differentiation process in the thymus [23].

Independently, another group generated transgenic mice carrying one of three human IGF2 minigenes containing different non-coding exons preceding the coding exons 7,8 and 9, spaced by truncated introns [24]. Those constructs were placed under transcriptional control of the $\mathrm{MHC} \mathrm{H}-2 \mathrm{~K}^{\mathrm{b}}$ promoter-enhancer. Overexpression of IGF-2 did not affect overall body growth, but provoked a marked thymic hyperplasia suggesting a role of IGF-2 in thymic development by paracrine/autocrine action. By in situ hybridization, transcripts of the $I G F 2$ transgene were found at high density in the thymic non-lymphoid medulla and in scattered positive cells in the thymic cortex. Intense IR IGF2 staining was observed by IHC with the same distribution of $I G F 2$ mRNA [25]. Moreover, IGF2 overexpression in these transgenic mice increases thymic cellularity and stimulates the production of normal mature $\mathrm{T}$ cells with a slight polarization towards the CD4+ phenotype [26].

The various components of the IGF axis have been described in the normal human thymus. Promoters P3 and P4 are active in the control of $I G F 2$ transcription by human TEC. Transcripts of type 1 and 2 IGF receptor genes were detected in human lymphoid Jurkat $\mathrm{T}$ cells but not in cultured human TEC. By Northern blot analyses, genes encoding IGF-binding protein (IGFBP)-2 to -6 (but not IGFBP-1) are expressed in TEC with a dominance of IGFBP-4. Lymphoid Jurkat T cells only express IGFBP-2, but at quite high levels [27].

The functional relevance of the thymic insulin-like growth factor axis has been investigated using murine fetal thymic organ cultures (FTOC). In murine fetal thymic lobes, Igf 2 and Igfl transcripts were detected in TEC and macrophages, respectively [28]. Treatment of FTOC with an anti-IGF-1 antibody did not affect thymopoiesis. However, T cell differentiation at early stages (CD4-8-, double negative) was severely inhibited when FTOC were treated with antibodies against IGF-2, IGF type 1 receptor, and even IGF type 2 receptor [28]. In addition, proinsulin did not affect thymopoiesis or T cell differentiation in this FTOC model. Such findings and the thymopoietic effects of IGF-2 overexpression in a transgenic model strongly suggest that IGF-2, rather than IGF-1 and insulin, is an important tissue factor for thymopoiesis.

\section{CENTRAL SELF-TOLERANCE OF THE INSULIN FAMILY}

The members of the insulin gene family are all transcribed in the thymic stromal cells with a precise topography and hierarchy in their respective expression level. As discussed above, IGF2 is transcribed by TEC in the whole cortex and in medulla, while IGF1 is expressed by thymic macrophages. INS is transcribed by some subsets of medullary TEC [29], and these cells are now identified as a unique cell type that can express "promiscuously" and randomly a large number of tissue-specific genes with the potential to induce the central self-tolerance of peripheral tissue antigens [15]. Thus, immune self-tolerance of a family that is crucial for vital aspects such as fetal development, postnatal growth and glucose metabolism is established at the central level through the intrathymic expression of INS, $I G F 1$ and $I G F 2$. 
Experimental evidence also exists that the degree of tolerance to a given protein is closely correlated with its intrathymic concentration [30,31]. In parallel with this hierarchy, immune tolerance of IGF-2 is higher than IGF-1, and much more than insulin. This is indirectly reflected by the frequency and titer of antibodies obtained after active immunization with the three peptides [32]. In the same line of reasoning, the high occurrence of anti-insulin autoantibodies in the normal population [33] could be linked to the low level of INS expression within the human thymus. The IGF- 2 protein contains peptide sequences that have been highly conserved throughout evolution of the insulin family. Because of this close homology, thymic IGF-2 would be a good candidate for inducing central immune self-tolerance of the whole insulin family although the tolerance to insulin per se would be weaker. This again might explain why B- and Tcell autoreactivity to insulin has been equally observed in diabetic and related non-diabetic individuals [33].

\section{INTRATHYMIC DEVELOPMENT OF THE DIABETOGENIC AUTOIMMUNE RESPONSE}

Until recently, the question of a defect in the thymic establishment of self-tolerance has not been intensively investigated as a factor involved in the development of the diabetogenic autoimmune response specifically directed against insulin-secreting islet $B$ cells. However, data from several studies add to the confirmation of this hypothesis. Already in 1982, neonatal thymectomy was shown to prevent the emergence of diabetes in an animal model of type 1 diabetes (T1D), the Bio-Breeding (BB) rat [34]. The therapeutic benefit of thymectomy might in fact result from the removal of a defective thymic censorship responsible for a continuous release and enrichment of the peripheral $\mathrm{T}$ cell pool with self-reactive $\mathrm{T}$ cell clones. In contrast, the occurrence of diabetes is prevented by the transplantation of thymus from diabetes-resistant (BBDR) to diabetes-prone (BBDP) BB rats [35]. Thymus transplantation from NOD mice to diabetes-resistant mouse strains was also shown to induce autoimmune diabetes in the recipients [36]. Grafts of pure thymic epithelium from NOD mouse embryos to newborn C57BL/6 athymic mice induced CD4 and CD8 T cell-mediated insulitis and sialitis [37]. At the histological level, a defect in thymus tolerogenic function could result from disorganization in the tissue environment such as the presence of giant perivascular spaces as observed in the NOD mouse thymus [38]. Epithelial defects have also been characterized in the thymus of BB rats [39].

The development of the diabetogenic autoimmune process may result from a defect in the establishment of thymic central self-tolerance through abnormalities of transcription or processing of $\beta$ cell-specific autoantigenencoding genes. Igf 2 transcripts could not be found in the thymus of more than $80 \%$ BBDP rats, in close accordance with the incidence of diabetes in this BB rat strain $(86 \%)$ [40]. This gene defect was specific of the thymus since Igf2 mRNA was evidenced in brain and liver of BBDR rats. Two independent groups have shown that the levels of INS transcripts were low in the thymus from deceased fetuses with genetic susceptibility to T1D (presence of VNTR class I alleles), while they were higher in thymi from fetuses bearing protective alleles (VNTR class III alleles) [41,42]. Another study has also reported low expression of insulin within the thymus of NOD mice [43] while mice with thymus-restricted insulin defect developed a strong proinsulin-specific $\mathrm{T}$ cell reactivity [44]. Also, an acceleration of autoimmune diabetes is observed in NOD mice with drastically reduced Ins 2 expression [45]. Thus despite its low expression in the thymus, insulin also contributes to central self-tolerance. It remains to be further determined whether this contribution could be mediated through the generation of insulin-specific $\mathrm{T}$ cells. With regard to other $B$ cell autoantigens, it is interesting to note that GAD67 is the dominant GAD isoform expressed in the thymus whereas GAD65 is the autoantigen implicated in the peripheral diabetogenic autoimmunity against $B$ cells [46]. The protein AIRE (AutoImmune Regulator) is a transcription factor involved in the control of intrathymic expression of "promiscuous" genes encoding peripheral autoantigens [4749]. Several mutations of the AIRE gene are responsible for the development of autoimmune polyglandular syndrome type 1 (APS-1) or APECED syndrome (Autoimmune PolyEndocrinopathy, Candidiasis and Ectodermal Dystrophy). AIRE expression is maximal in the thymus [50,51], and thymus transplantation from Aire ${ }^{-/-}$mice to normal mice is followed by the appearance of several autoimmune lesions in grafted mice [52]. The profile of gene expression was studied by microarrays in the thymus of Aire ${ }^{-/-}$mice, and thymic levels of transcripts from several genes (including Igf 2, Ins2, Ot and neuropeptide $Y$ ) were severely decreased in those thymi compared to normal ones [53].

\section{PHARMACOLOGICAL PERSPECTIVES: THE THYMUS AS A TARGET FOR A NOVEL TYPE OF VACCINES}

The study of neuroendocrine gene expression and precursor processing in the thymus led to the identification of thymic neuroendocrine self-antigens. With regard to insulin-related gene expression in the thymus, IGF-2 - a prominent fetal growth factor - was identified as the dominant self-peptide precursor of the insulin family expressed in the thymus epithelium from different species, including man. This observation is in close accordance with the theory of self-recognition, which, according to F.M. Burnet, is not an inherited property but is gradually acquired in the course of fetal life [54]. The tolerogenic properties of thymic neuroendocrine self-peptides are already suspected from what is known about the immunological tolerance of classic hormones. The development of specific antibodies by active immunization (i.e. experimental breakdown of selftolerance) revealed that OT is more tolerated than VP, and that IGF-2 is also more tolerated than IGF-1, and much more than insulin [32]. Some cases of diabetes insipidus arise from an autoimmune process against VP-producing hypothalamic neurons. Insulin is the primary autoantigen tackled by the autoimmune process observed in T1D, and this might result from its very low expression in the thymus. At the opposite, autoimmunity has never been reported against OT and IGF2 . The very strong tolerance of these peptides, resulting from high expression of their genes in the thymus, may be considered as the consequence of evolutionary pressure to 
protect from autoimmunity species reproduction and individual ontogeny. In parallel with a physiological role of the thymus in the establishment of central immune selftolerance, a thymus defective for this censorship of selfreactivity more and more appears to exert a crucial influence in the development of organ-specific autoimmunity. Already in 1973, F.M. Burnet hypothesized and provided some preliminary data supporting this novel concept according to which the origin of autoimmunity resides in a defect in selftolerance setting (programming) during the process of $\mathrm{T}$ cell differentiation within the thymus environment [55]. Consequently, an efficient and secure prevention and/or cure of devastating autoimmune diseases such as T1D could be based upon knowledge of the powerful tolerizing mechanisms in the thymus. Such strategy may firstly rely on the dominant IGF-2 derived thymic self-antigen(s) of the insulin family. As previously said, insulin is poorly expressed in the thymus and this fact may explain why insulin - and insulin-derived epitopes - appears so immunogenic in some experimental models [56, 57]. Similarly, insulin administered either orally or subcutaneously does not exert any tolerogenic effect that could protect the residual $B$-cell mass from the destructive autoimmune process [58-60].

On the basis of the hierarchy in the intrathymic expression of insulin-related genes, we explore the hypothesis that IGF-2 would be a more appropriate choice for designing an antigen-driven tolerogenic approach in T1D prevention. In this novel type of tolerogenic vaccination, administration of self-peptide(s) derived from IGF-2 could anergize or delete self-reactive $\mathrm{T}$ cells that have escaped the central censorship because of a thymus dysfunction in the establishment of $\beta$-cell self-tolerance. Preliminary analyses revealed that the major autoantigenic epitope of insulin (sequence B9-23) and the homologous sequence B11-25 of IGF-2 share the same affinity and equally compete for binding to DQ8, a MHC class II allele conferring major susceptibility to TID (Wûcherpfennig, personal communication). In a preclinical study, we investigated the cytokine profile elicited by the DQ8 presentation of these sequences to PBMCs isolated from ten T1D DQ8+ adolescents [61].

As shown in (Fig. 1), IGF-2 B:11-25 presentation is associated with a regulatory/tolerogenic profile (high IL-10 and IL-10/IFN- $\gamma$ ratio). These first data document the potent tolerogenic and IL-10 inducing properties of an IGF-2 deriv-
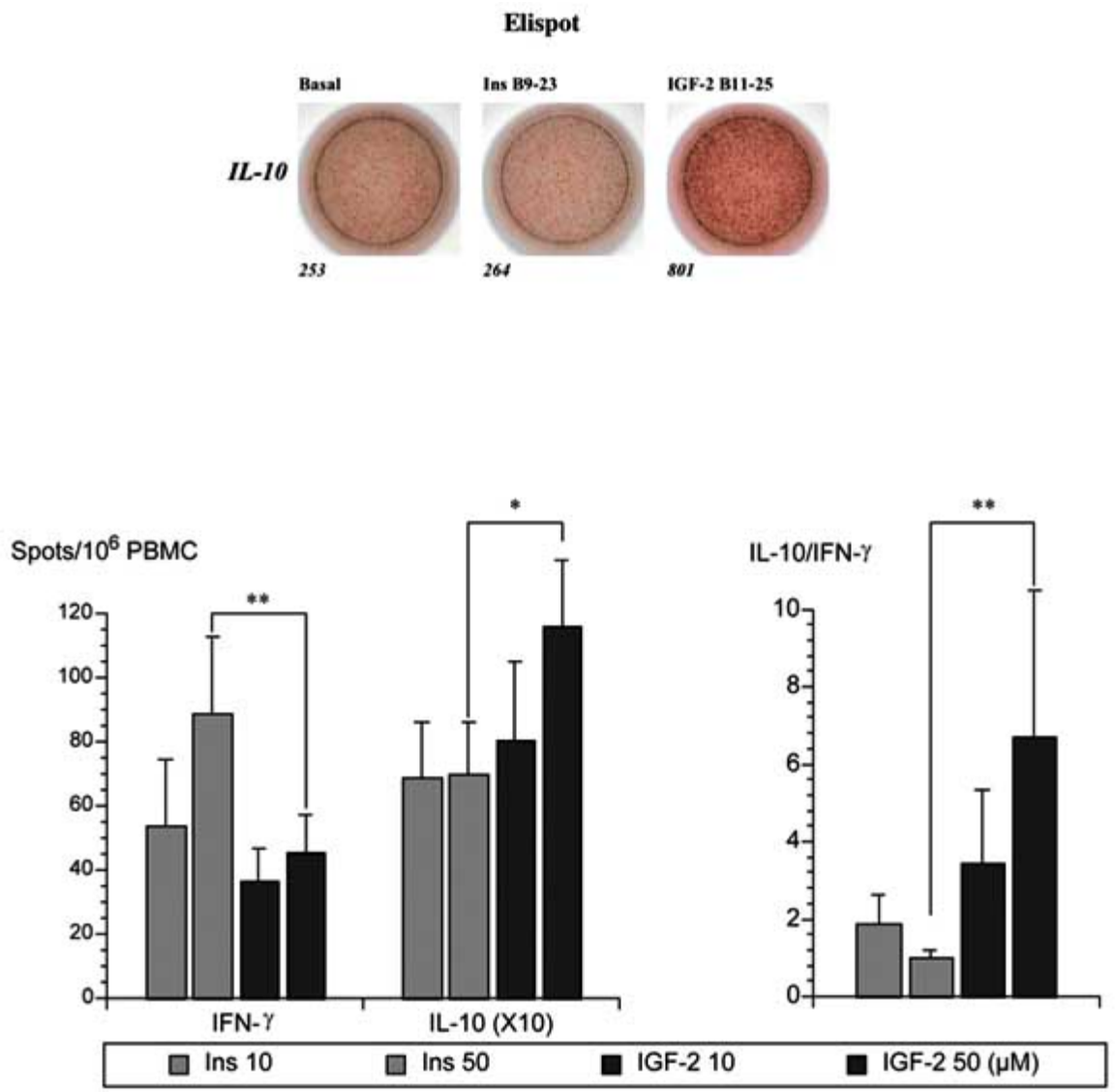

Fig. (1). IL-10 and IFN- $\gamma$ responses measured by Elispot assay in cultures of PBMCs isolated from DQ8+ T1D children and adolescents (6 females and 4 males; age range 7-16 years) treated with Ins B9-23 or IGF-2 B11-25 at two doses (10 and 50 $\mu$ M). Mean \pm SEM; N = 10; * P $<0.05 ; * * \mathrm{P}<0.01$ by Wilcoxon's test. 
ed peptide and may explain why it is difficult to obtain antibodies directed to IGF-2 at high titers after active immunization with this protein. Therefore, with regard to T1D prevention, administration of IGF-2 derived selfantigen(s) constitutes an innovative approach that combines antagonism with a dominant Ins autoantigen for binding to a major susceptibility MHC-II allele, as well as promotion of a specific antigen tolerogenic response. The complete design of an efficient and safe tolerogenic vaccination procedure could include self-antigen sequences derived from GAD67 and protein derived from alternatively spliced IA-2 that are dominantly expressed in the thymus for presentation to pre-T cells.

\section{ACKNOWLEDGEMENTS}

Our studies are supported by the Special Research Fund of Liege University, by Fondation Leon Fredericq (Liege University Hospital), by the National Fund of Scientific Research (NFSR) of Belgium, by FRIA (Belgium), by Fondation Vaugrenier pour la Recherche en Tolérance (Geneva), by EASD (Düsseldorf), and by European Union FP6.

\section{REFERENCES}

[1] Benoist, C.; Mathis, D. T-lymphocyte Differentiation and Biology. In: Paul, W.E. (ed). Fundamental Immunology $4^{\text {th }}$ Edition. Philadelphia: Lippincott-Raven, 1999, 367-409.

[2] Mason, D.; Powrie, F. Curr. Opin. Immunol., 1998, 10, 649-655.

[3] Sakagushi, S. Nat. Immunol., 2001, 2, 283-284.

[4] Kamradt, T.; Mitchison, N.A. N. Engl. J. Med., 2001, 344, 655664.

[5] Bennett, A.R.; Farley, A.; Blair, N.F.; Gordon, J.; Sharp, L.; Blackburn, C.C. Immunity, 2002, 16, 803-814

[6] Girr, J.; Malin, M.; Holländer, G.A.; Boyd, R. Nat. Immunol., 2002, 3, 635-642.

[7] Penninger, J.; Rieker, T.; Romani, N.; Klima, J.; Salvenmoser, W.; Dietrich, H.; Stössel, H.; Wick, G. Eur. J. Immunol., 1993, 24, 222229.

[8] Scollay, R. T lymphocytes. In: Roitt, I.M.; Delves, P.J. (Eds).; Encyclopedia of Immunology.; First Edition. London: Academic Press, 1992, 1473-1475.

[9] Ashton-Rickardt, P.G.; Tonegawa, S. Immunol. Today, 1994, 15, 362-366.

[10] Geenen, V.; Robert, F.; Martens, H.; De Groote, D.; Franchimont, P. J. Endocr. Invest., 1992, 15, 621-629.

[11] Robert, F.; Martens, H.; Cormann, N.; Benhida, A.; Schoenen, J.; Geenen, V. Dev. Immunol., 1992, 2, 131-140.

[12] Jolicoeur, C.; Hanahan, D.; Smith, K.M. Proc. Natl. Acad. Sci. USA, 1994, 91, 6707-6711.

[13] Hanahan, D. Curr. Opin. Immunol., 1998, 10, 656-662.

[14] Savino, W.; Dardenne, M. Endocr. Rev., 2000, 21, 412-443.

[15] Kyewski, B.; Derbinski, J.; Gotter, J.; Klein, L. Trends Immunol., 2002, 23, 364-371.

[16] Geenen, V.; Legros, J.J.; Franchimont, P.; Baudrihaye, M.; Defresne, M.P.; Boniver, J. Science, 1986, 232, 508-511.

[17] Ericsson, A.; Geenen, V.; Robert, F.; Legros, J.J.; Vrindts-Gevaert, Y.; Franchimont, P.; Brene, S.; Persson, H. Mol. Endocr., 1990, 4 , 1211-1218.

[18] Funder, J.W. Mol. Cell. Endocrinol., 1990, 70, C21-C24.

[19] Geenen, V.; Goxe, B.; Martens, H.; Vandersmissen, E.; Vanneste, Y.; Achour, I.; Kecha, O.; Lefebvre, P.J. J. Mol. Med., 1995, 73, 449-455.

[20] Geenen, V.; Vandersmissen, E.; Martens, H.; Cormann-Goffin, N.; Degiovanni, G.; Legros, J.J.; Benhida, A.; Martial, J.; Franchimont, P. Thymus, 1993, 22, 55-66.

[21] Vanneste, Y.; Ntodou-Thome, A.; Vandersmissen, E.; Charlet, C.; Franchimont, D.; Martens, H.; Schimpff, R.M.; Rostene, W.; Geenen, V. J. Neuroimmunol., 1997, 76, 161-166.
[22] Geenen, V.; Brilot, F.; Hansenne, I.; Charlet, C.; Martens, H.; Thymus and $\mathrm{T}$ Cells. In: Adelman G.; Smith BH (eds). Encyclopedia of Neuroscience $3^{\text {rd }}$ Edition. New York: Elsevier, 2003, in press.

[23] Geenen, V.; Achour, I.; Robert, F.; Vandersmissen, E.; Sodoyez, J.C.; Defresne, M.P.; Boniver, J.; Lefebvre, P.J.; Franchimont, P. Thymus, 1993, 21, 115-127.

[24] van Buul-Offers, S.C.; de Haan, K.; Reijnen-Gresnigt, M.G.; Meinsma, D.; Jansen, M.; Oei, S.L.; Bonte, E.J.; Sussenbach, J.S.; Van den Brande, J.L. J. Endocrinol., 1995, 144, 491-502.

[25] Van der Ven, L.T.M.; Roholl, P.J.M.; Reijnen-Gresnigt, M.G.; Bloemen, R.J.; van Buul-Offers, S.C. Histochem. Cell. Biol., 1997, 107, 193-203.

[26] Kooijman, R.; van Buul-Offers, S.C.; Scholtens, L.E.; Schuurman, H.J.; Van den Brande, L.J.; Zegers, B.J.M. J. Immunol., 1995, 154, 5736-5745.

[27] Kecha, O.; Martens, H.; Franchimont, N.; Achour, I.; HazéeHagelstein, M.T.; Charlet-Renard, C.; Geenen, V.; Winkler, R. J. Neuroendocrinol., 1999, 11, 435-440.

[28] Kecha, O.; Brilot, F.; Martens, H.; Franchimont, N.; Renard, C.; Greimers, R.; Defresne, M.P.; Winkler, R.; Geenen, V. Endocrinology, 2000, 141, 1209-1217.

[29] Derbinski, J.; Schulte, A.; Kyewski, B.; Klein, L. Nat. Immunol., 2001, 2, 1032-1039.

[30] Egwuagu, C.E.; Charukamnoetkanok, P.; Gery, I. J. Immunol., 1997, 3109-3112.

[31] Sospedra, M.; Ferrer-Francesch, X.; Dominguez, O.; Juan, M.; FozSala, M.; Pujol-Borrell, R. J. Immunol., 1998, 161, 5918-5929.

[32] Zapf, J.; Walter, H.; Froesch, E.R. J. Clin. Invest., 1981, 68, 13211330.

[33] Naquet, P.; Ellis, J.; Tibensky, D.; Kenshole, A.; Singh, B.; Hodges, R.; Delovitch, T.L. J. Immunol., 1988, 140, 2569-2578.

[34] Like, A.A.; Kislaukis, E.; Williams, R.M.; Rossini, A.A. Science, 1982, 216, 644-646.

[35] Georgiou, H.M.; Bellgrau, D. J. Immunol., 1989, 142, 3400-3405.

[36] Georgiou, H.M.; Mandel, T.E. Diabetes, 1995, 44, 49-59.

[37] Thomas-Vaslin, V.; Damotte, D.; Coltey, M.; Le Douarin, N.M.; Coutinho, A.; Salaün, J. Proc. Natl. Acad. Sci. USA, 1997, 94, 45984603.

[38] Savino, W.; Carnaud, C.; Luan, J.J.; Bach, J.F.; Dardenne, M. Diabetes, 1993, 42, 134-140.

[39] Doukas, J.; Mordes, J.P.; Swymer, C.; Niedzwiecki, D.; Mason, R.; Rozing, J.; Rossini, A.A.; Greiner, D.L. Am. J. Pathol., 1994, 145, 1517-1525.

[40] Kecha-Kamoun, O.; Achour, I.; Martens, H.; Collette, J.; Lefebvre, P.J.; Greiner, D.L.; Geenen, V. Diabetes/Metab. Res. Rev., 2001, 17, 146-152.

[41] Vafiadis, P.; Bennett, S.T.; Todd, J.A.; Nadeau, J.; Grabs, R.; Goodyer, C.G.; Wickramasinghe, S.; Colle, E.; Polychronakos, C. Nat. Genet., 1997, 15, 289-292.

[42] Pugliese, A.; Zeller, M.; Fernandez, A. Jr.; Zalcberg, L.J.; Bartlett, R.J.; Ricordi, C.; Pietropaolo, M.; Eisenbarth, G.S.; Bennett, S.T.; Patel, D.D. Nat. Genet., 1997, 15, 293-297.

[43] Brimnes, M.K.; Jensen, T.; Jorgensen, T.N.; Michelsen, B.K.; Troelsen, J.; Werdenlin, O. J. Autoimmun., 2002, 19, 203-213.

[44] Chentoufi, A.A.; Polychronakos, C. Diabetes, 2002, 51, 1383 1390.

[45] Thebault-Baumont, K.; Dubois-Laforgue, D.; Krief, P.; Briand, J.P.; Halbout, P.; Vallon-Geoffroy, K.; Morin, J.; Laloux, V.; Lehuen, A.; Carel, J.C.; Jami, J.; Muller, S.; Boitard, C. J. Clin. Invest., 2003, 111, 851-857.

[46] Kaufman, D.L.; Clare-Salzler, M.C.; Tian, J.; Forsthuber, T.; Ting, G.S.P.; Robinson, P.; Atkinson, M.A.; Sercarz, E.E.; Tobin, A.J.; Lehmann, P.V. Nature, 1993, 366, 69-72.

[47] Diez, J.; Park, Y.; Zeller, M.; Brown, D.; Garza, D.; Ricordi, C.; Hutton, J.; Eisenbarth, G.S.; Pugliese, A. Diabetes, 2001, 50, 895900 .

[48] Nagamine, K.; Peterson, P.; Scott, H.S.; Kudoh, J.; Minoshima, S.; Heino, M.; Krohn, K.J.E.; Lalioti, M.D.; Mullis, P.E.; Antonorakis, S.E.; Kawasaki, K.; Asakawa, S.; Ito, F.; Shimizu, N. Nat. Genet., 1997, 17, 393-398.

[49] Rossier, M.L.; Heino, M.; Peterson, P.; Krohn, K.J.; Gos, A.; Morris, M.A.; Kudoh, J.; Shimizu, N.; Antonarakis, S.E.; Scott, H.S. Biochem. Biophys. Res. Commun., 1999, 255, 483-490. 
[50] Pitkänen, J.; Peterson, P. Genes and Immunity, 2003, 4, 12-21.

[51] Zuklys, S.; Balciunaite, G.; Agarwal, A.; Farler-Kan, E.; Palmer, E.; Holländer, G.A. J. Immunol., 2000, 165, 1976-1983.

[52] Heino, M.; Peterson, P.; Silanpää, N.; Guerin, S.; Wu, L.; Anderson, G.; Scott, H.S.; Antonarakis, S.E.; Kudoh, J.; Shimizu, N.; Jenkinson, E.J.; Naquet, P.; Krohn, K.J. Eur. J. Immunol., 2000, 30, 1884-1893.

[53] Anderson, M.S.; Venanzi, E.S.; Klein, L.; Chen, Z.; Berzins, S.P.; Turley, S.J.; Von Boehmer, H.; Bronson, R.; Dierich, A.; Benoist, C.; Mathis, D. Science, 2002, 298, 1395-1301.

[54] Burnet, F.M. The Clonal Selection Theory of Acquired Immunity. Cambridge University Press, Cambridge 1959.

[55] Burnet, F.M. Aust. J. Exp. Biol. Med. Sci., 1973, 50, 1-9.

[56] Gottlieb, PA. Clin. Immunol., 2002, 102, 2-11.

[57] Liu, E.; Moriyama, H.; Abiru, N.; Miao, D.; Yu, L.; Taylor, R.M.; Finkelman, F.D.; Eisenbarth, G.S. J. Clin. Invest., 2002, 110, 10211027.
[58] Chaillous, L.; Lefevre, H.; Thivolet, C.; Boitard, C.; Lahlou, N.; Atlan-Gegner, C.; Bouhanick, B.; Mogenet, A.; Nicolino, M.; Carel, J.C.; Lecomte, P.; Marchenaud, R.; Bougneres, P.; Charbonnel, B.; Sai, P. Lancet, 2000, 356, 545-549.

[59] Pozzilli, P.; Pitocco, D.; Visalli, N.; Cavallo, M.G.; Buzzetti, R.; Crino, A.; Spera, S.; Suraci, C.; Multari, G.; Cervoni, M.; Manca, Bitti, M.L.; Matteoli, M.C.; Marietti, G.; Ferrazzoli, F.; Cassone Faldetta, M.R.; Giordano, C.; Sbriglia, M.; Sarugeri, E.; Ghirlanda, G. Diabetologia, 2000, 43, 1000-1004.

[60] DPT-Type 1 diabetes Study Group. Effects of insulin in relatives of patients with type 1 diabetes. N. Engl. J. Med., 2002, 346, 16851691.

[61] Geenen, V.; Brilot, F.; Hansenne, I.; Louis, C.; Martens, H.; Wücherpfennig, K.; Gorus, F. Diabetologia, 2003, 46 (Suppl. 2), A10, abstract 22 . 